\title{
Measuring Fiscal Multipliers in Egypt: Applying the Bucket and SVAR Approaches
}

\author{
Dr. Sahar M. Abdel-Haleim \\ Lecturer of Economics \\ Faculty of Business Administration, \\ Economics and Political Science, \\ The British University \\ Arab Republic of Egypt \\ sahar.halim@bue.edu.eg
}

\begin{abstract}
Contrary to the Keynesian view, quantifying the fiscal multipliers in Egypt yields small magnitude using empirical and non-empirical approaches. The effectiveness of fiscal policy is analyzed using two approaches. Firstly, the 'Bucket approach' deduces the size of fiscal multipliers within the framework of several structural factors that are believed to have a significant effect in determining the size of fiscal multiplier. This represents the first such study that applies the "Bucket approach" in the case of Egypt. Secondly, the Structural Vector Auto-Regression (SVAR) approach is estimated over the period (2005/06 - 2017/18) with quarterly data. This high-frequency data enables identifying the SVAR model through imposing the contemporaneous restrictions. The model includes government expenditures, tax revenues, output and interest rate in real terms. The findings of the 'Bucket approach' and SVAR were consistent and confirm a limited Keynesian demand push effect. Government spending proves to be much more effective tool than the tax revenues.
\end{abstract}

JEL:E60; H3O; C32

Keywords: Fiscal Multipliers, Government expenditures, Tax revenues, Bucket approach, Structural Vector Autoregression (SVAR).

\section{Introduction}

Fiscal policy has a significant impact on micro decisions and macroeconomic activity through its effect on disposable income, consumption, saving and investment. Hence, a good understanding of the effect of fiscal policy in terms of its size, timing and channels is critical to stabilize any economy. Fiscal multipliers refer to the output response to a discretionary fiscal policy. Accurate measure of fiscal multipliers is crucial in macroeconomic forecast accuracy, in addition to policy design and advice. According to Eyraud and Weber (2013), underestimation of fiscal multipliers could negatively affect the credibility of fiscal consolidation programs. That is because fiscal targets will not be met and debt to GDP ratio could not be reduced.

The impact of fiscal policy has received less attention compared to monetary policy analysis because estimating fiscal multipliers is a complicated process. There is a two-way relationship between the fiscal policy instruments and output; government spending as well as taxes respond automatically to fluctuations in the business cycle. Hence, it is difficult to isolate the direct effects of exogenous shocks of policy instruments on output.

* This article was submitted in August 2021, and accepted for publishing in September 2021.

(c) Arab Administrative Development Organization- League of Arab States, 2024, pp 239-256، D DOI: 10.21608/aja.2021.88851.1128 
According to the Economic Governance Support Unit note of the European Parliament (2013), there is no agreement on a standard value for the fiscal multiplier. The reason behind this is that there are many factors that determine the value of the multiplier such as the used econometric model, the structure of the economy, the nature and duration of the fiscal effect, the composition of the fiscal change, the size of public debt, the propensity to consume and import, other financial and monetary conditions and issues that affect the public's confidence.

In fact, the size of fiscal multipliers has been a subject of debate. However, researches in fiscal policy and its multiplier effect have been recently revived as a result of: (i) the increasing use of fiscal stimulus packages as a stabilization tool; (ii) the application of the VAR approach to analyze fiscal policy; and (iii) the urgent need for many economies to undertake fiscal consolidation measures.

The purpose of this paper is to investigate the effect of Egypt's fiscal policy through quantifying the fiscal multipliers with the two main fiscal instruments; namely government expenditures and tax revenues. Towards this purpose, non-empirical and empirical methods have been utilized in this paper. With regards to the first method, the 'bucket approach' has been applied to deduce the size of fiscal multipliers. This approach was initially suggested by Batini et al. (2014a, b) particularly for countries that suffer from lack of data. This approach depends on certain economic characteristics that are believed to have a significant effect in determining the size of fiscal multiplier. It is worth noting that this is the first such study that applies the "Bucket approach" in the case of Egypt.

Considering the empirical approach, a four-variable Structural Vector Autoregression (SVAR) model is utilized across 2005/06 - 2017/18 using quarterly data. This high-frequency data enables identifying the SVAR model through imposing the contemporaneous restrictions. The model includes government expenditures, tax revenues, output and interest rate in real terms. Also, the real interest rate is included as a monetary policy instrument to reflect the interaction between monetary and fiscal policies.

The motivations behind this paper can be summed up as follows: (i) measuring the effect of expansionary fiscal policy on output will reveal the effectiveness of fiscal policy in stimulating economic activity; (ii) including two fiscal policy tools, namely government spending and tax revenues allows to assess the contribution of each tool in the fiscal stimulus package; and (iii) contributing to the limited number of empirical studies in this field.

The paper is structured as follows: Section II presents theoretical and empirical reviews of the subject. Section III discusses the 'Bucket approach' and its main determinants with an application on Egypt. Section IV outlines the specification of the SVAR and the identification method. Section V presents the empirical results followed by a discussion in section VI. Finally, section VII presents conclusion and policy recommendations.

\section{Literature Review}

\section{Theoretical Review}

Although the concept of fiscal multiplier goes back historically to "Tableau Economique" of Francois Quesnay (1758), it became a central concept in macroeconomic theory after the General theory of John Maynard Keynes (1936). It is defined as the ratio of a change in output $(Y)$ to an exogenous change in a fiscal policy instrument $(G)$ at the time in which the impulse to a fiscal policy instrument occurs, such that:

$$
\Delta \mathrm{Yt} / \Delta \mathrm{Gt}
$$

A distinction must be made between the above impact multiplier and the cumulative multiplier, which refers to the estimation of fiscal policy over longer forecast horizons as follows:

$$
\sum_{\mathrm{j}=0}^{\mathrm{n}} \Delta \mathrm{Y}_{\mathrm{t}+\mathrm{j}} / \sum_{\mathrm{j}=0}^{\mathrm{n}} \Delta \mathrm{G}_{\mathrm{t}+\mathrm{j}}
$$


The cumulative fiscal multiplier measures the cumulative change in output per unit of additional fiscal policy instrument that extends to the reported horizon.

Since the global financial crisis in 2008, there has been an increasing interest in estimating the effect of fiscal multipliers on output. However, considerable debate over the size and nature of fiscal multipliers persist. Estimating the magnitude of fiscal multipliers developed from the Keynesian-based ISLM models to more Neoclassical-based Real Business Cycle models. In the former methodology, estimates of fiscal multipliers are positive and higher than one, whereas in the latter method, fiscal multiplier values range between zero and one (Mustea, 2015).

Estimating fiscal multipliers is a complicated process. There is a two-way relationship between the fiscal policy instruments and output; hence it is difficult to isolate the direct effects of exogenous shocks of policy instruments on output. Empirical literature used to utilize two main methods: model based approaches and empirical estimations.

First, the model-based approaches use advanced models to stimulate fiscal shocks such as the Dynamic Stochastic General Equilibrium (DSGE) models. Different models have been evolved from the DSGE models such as; real business cycle (RBC) models (for instance, Leeper et al., 2011) and New Keynesian (NK) models (for instance, Christiano et al., 2012). Second, empirical estimation employs the Vector Autoregressive (VAR) models. There are three main Identification problems to identify fiscal policy shocks within the VAR model. First, a proper distinction is required between movements in fiscal variables that are due to fiscal policy shocks or to other shocks such as monetary policy shocks or business cycle. Second, an agreement on a definition for a fiscal policy shock. Third, the existing lag between announcement and implementation of fiscal policy. In this regard, four main identification approaches are utilized:

1- Narrative approach: known as the dummy variable or the event study approach developed by Ramey and Shapiro (1998) to identify the periods of military build-ups for the US economy. They captured the dynamic effects of a government spending shock by constructing dummy variables for the increase in government defense spending. They found that private consumption response to a fiscal policy shock was negative.

2- Calibrated elasticities: This approach is applied by Blanchard and Perotti (2002) in which they combine institutional information in their trivariate SVAR model. This identification scheme is widely used in most analysis to estimate fiscal multipliers using structural VAR and panel VAR.

3- Sign restrictions: Montford and Uhlig (2002) developed this approach to identify fiscal shocks by using sign restrictions while controlling for the monetary and business cycle shocks. This approach unlike other approaches depends on macroeconomic time series data alone for shock identification and does not require a prior assumption about the variables responses.

4- Recursive structure: The VAR model is identified using Cholesky decomposition (recursive ordering) as suggested by Sims (1980). Fatas and Mihov (2001) applied this approach to identify the fiscal shocks in a three variables VAR model, namely government spending, output and taxes. Though its simplicity, this method is strongly sensitive to the ordering of variables.

\section{Empirical Literature}

A number of empirical literatures estimated the size and type of fiscal multipliers and their effect on real output. Some of them used a panel data for a group of countries with varying classification of development, while others focused on a specific case study (Table (1)). Discrepancies in the estimates of fiscal multipliers could result from different methodologies, data sets, the period under analysis and primary behavioral assumptions (Whalen and Reichling, 2015). 
TABLE (1) A Summary of Selected Empirical Studies

\begin{tabular}{|c|c|c|c|c|}
\hline Author/s & Period & Countries & Methods / Variables & Findings \\
\hline $\begin{array}{l}\text { Blanchard } \\
\text { \& Perotti } \\
(2002) \\
\end{array}$ & $\begin{array}{l}1949: 1- \\
1959: 4\end{array}$ & $\begin{array}{l}\text { The United } \\
\text { States }\end{array}$ & $\begin{array}{c}\text { SVAR/government } \\
\text { purchases, tax revenues } \\
\text { and GDP. }\end{array}$ & $\begin{array}{l}\text { Government spending and tax revenues multipliers } \\
\text { are small. }\end{array}$ \\
\hline $\begin{array}{l}\text { Cerisola et al. } \\
\qquad(2015)\end{array}$ & $\begin{array}{l}1990- \\
2008\end{array}$ & $\begin{array}{l}19 \text { MENAP } \\
\text { countries }\end{array}$ & $\begin{array}{l}\text { VAR with sign restrictions } \\
\text { / tax revenues, current } \\
\text { spending, government } \\
\text { consumption and gov- } \\
\text { ernment investment. }\end{array}$ & $\begin{array}{l}\text { Average fiscal multipliers are small ( } 0.5 \text { to } 0.8) \text { except } \\
\text { government investment which exceeds unity. How- } \\
\text { ever, tax revenues multipliers are }-0.4 \text {. Variations are } \\
\text { due to disparities in economic characteristics. }\end{array}$ \\
\hline $\begin{array}{l}\text { Ilzetzki, et al. } \\
\qquad(2011)\end{array}$ & $\begin{array}{l}1960: 1- \\
2007: 4\end{array}$ & $\begin{array}{l}\text { A panel of } 20 \\
\text { high-income } \\
\text { and } 24 \text { devel- } \\
\text { oping countries }\end{array}$ & $\begin{array}{l}\text { SVAR / government } \\
\text { consumption and in- } \\
\text { vestment spending, GDP, } \\
\text { Current account, real } \\
\text { exchange rate, interest } \\
\text { rate. }\end{array}$ & $\begin{array}{l}\text { Government consumption multipliers are smaller in } \\
\text { developing countries than the developed ones. Gov- } \\
\text { ernment investment multipliers in developing and } \\
\text { high-income countries are close to } 1 \text {. Some economic } \\
\text { fundamentals reduce the fiscal multipliers: flexible } \\
\text { exchange rates, high degree of openness, outstanding } \\
\text { debt higher than } 60 \text { percent of GDP. }\end{array}$ \\
\hline Çebi (2015) & $\begin{array}{l}2001- \\
\text { post crisis } \\
\text { period. }\end{array}$ & Turkey & $\begin{array}{c}\text { SVAR method/spending, } \\
\text { taxes, output and interest } \\
\text { rate }\end{array}$ & $\begin{array}{l}\text { The multiplier exceeds one at the first few quarters } \\
\text { peaking in the second quarter. }\end{array}$ \\
\hline $\begin{array}{l}\text { Boiciuc } \\
(2015)\end{array}$ & $\begin{array}{l}2000: 1- \\
2012: 4\end{array}$ & Romania & $\begin{array}{l}\text { SVAR / Government } \\
\text { expenditure, RGDP, GDP } \\
\text { deflator, taxes, short- } \\
\text { term interest rate }\end{array}$ & Fiscal multipliers are very small. \\
\hline $\begin{array}{l}\text { Hamer-Ad- } \\
\text { ams \& Wong } \\
(2018)\end{array}$ & $\begin{array}{l}1990- \\
2017\end{array}$ & New Zealand & $\begin{array}{l}\text { SVAR / total government } \\
\text { spending, tax revenues } \\
\text { and output. }\end{array}$ & $\begin{array}{l}\text { Public consumption multiplier is large and positive, } \\
\text { while public investment multiplier is negative. }\end{array}$ \\
\hline
\end{tabular}

Source: Author's Summary

Empirical studies for Egypt's fiscal multipliers are limited. Abou Elseoud (2018) utilized a cointegration technique using annual data across 1980 - 2017. He calculated the four-sector multiplier and estimated the aggregate demand function. He recommended that the government should decrease the leakages in the circular flow of income and increase the contribution of investment, in addition to applying policies that reduce imports and consumption of both unnecessary and luxury goods.

Moreover, Alnashar (2017) used a Vector Error Correction Model across 2005:1 - 2016:4 She assessed the relationship between government spending and economic growth, taking into consideration the state of business cycle, the degree of accommodation of monetary policy to fiscal policy, the real exchange rate, and the degree of capital and trade openness. Her findings supported the small size of government spending multiplier which was estimated at 0.06 in the first year and reached 0.28 in the long-run over the whole period under study. However, Nafie \& Atlam (2019) found that the fiscal multiplier is positive and exceeds one in the first year, but turned to be negative in the subsequent years. Following Blanchard and Perotti (2002), they used a trivariate SVAR model across 1990:1 - 2015:4. Nevertheless, given the absence of quarterly data before 2005, data are extrapolated based on the seasonality during the period for which data is available.

\section{Non Empirical Approach}

The "Bucket Approach" was initially suggested by Batini et al. (2014a) to deduce fiscal multipliers, particularly for countries that suffer from lack of data. This approach depends on certain economic characteristics that are believed to have a significant effect in determining the size of fiscal multiplier as illustrated in table (2). 
TABLE (2) The Structural Characteristics of the Bucket Approach

\begin{tabular}{|c|c|}
\hline $\begin{array}{c}\text { Structural } \\
\text { Characteristics }\end{array}$ & Assessment \\
\hline Trade Openness & $\begin{array}{l}\text { High multipliers occur in countries with lower propensities to import because of low demand leakage } \\
\text { through imports. } \\
\begin{array}{r}\text { The country is considered closed economy, if the ratio of imports to domestic demand is below 30\% } \\
\text { on average over the past five years. }\end{array}\end{array}$ \\
\hline $\begin{array}{c}\text { Labor Market } \\
\text { Rigidities }\end{array}$ & $\begin{array}{l}\text { High multipliers exist in countries with more rigid labor markets, when they lead to lower wage flexi- } \\
\text { bility because rigid wages increase the output response to demand shocks. } \\
\text { High rigidity occurs if the country has strong labor unions and /or its labor market is strongly regulated. }\end{array}$ \\
\hline $\begin{array}{l}\text { Automatic } \\
\text { Stabilizers }\end{array}$ & $\begin{array}{l}\text { Smaller multipliers are associated with large automatic stabilizers, which offset part of the initial } \\
\text { impact of fiscal shock on output. } \\
\text { When the ratio of public spending to nominal GDP is below } 0.40 \text {, automatic stabilizers are considered small. }\end{array}$ \\
\hline $\begin{array}{l}\text { Exchange Rate } \\
\text { Regime }\end{array}$ & $\begin{array}{l}\text { Smaller multipliers exist in countries with flexible exchange rate because fluctuations of exchange } \\
\text { rate can offset the effect of fiscal shock on GDP. } \\
\text { Countries could be assigned a value of } 1 \text { with: no specific legal tender; Currency board; conventional peg; sta- } \\
\text { bilized arrangement; crawling peg and crawl-like arrangement, and countries within a single currency area. }\end{array}$ \\
\hline The Debt Level & $\begin{array}{l}\text { Smaller multipliers occur in high-debt countries since fiscal stimulus negatively affects credibility and } \\
\text { interest rate risk premium. }\end{array}$ \\
\hline \multicolumn{2}{|r|}{ Conjunctural (Temporary) Factors } \\
\hline State of Business Cycle & Fiscal multipliers are larger during recession than expansion. \\
\hline $\begin{array}{l}\text { Degree of monetary } \\
\text { accommodation to } \\
\text { fiscal shocks }\end{array}$ & Expansionary monetary policy eliminate the contractionary effect of fiscal policy on demand. \\
\hline
\end{tabular}

Source: Batini, N.; Eyraud, L.; Forni, L. and Weber, A. (2014b). Fiscal Multipliers: Size, Determinants and Use in Macroeconomic Projections. IMF Technical Notes and Manuals.

Afterwards, the choice of fiscal multipliers in the first year is fulfilled in three stages. First, the country's scores are allocated based on its structural characteristics. Second, the first-year multiplier is calculated by summing up the scores with the assumption of normal times. Table (3) illustrates the ranges of first-year multipliers in normal times.

Third, the size of fiscal multipliers is modified based on two conjunctural (temporary) factors, which are:

1- The state of the business cycle: In general, fiscal multipliers tend to be larger during downturns than expansions. Empirical evidences indicate that the increase in fiscal multiplier during recession exceeds its decrease during expansion (Auerbach \& Gorodnichenko (2012), Batini et al. (2012) and Owyang et al. (2013)). If the economy passes through the trough phase, the upper and lower bound should be raised by 60 percent. While, if the economy

TABLE (3) First-Year Multipliers Ranges in Normal Times

Country Multiplier Classification Ranges

\begin{tabular}{cc}
\hline Low & $0.1-0.3$ \\
\hline Medium & $0.4-0.6$ \\
\hline High & $0.7-1.0$ \\
\hline
\end{tabular}

Source: Batini, N.; Eyraud, L.; Forni, L. and Weber, A. (2014b). Fiscal Multipliers: Size, Determinants and Use in Macroeconomic Projections. IMF Technical Notes and Manuals. is at the peak phase, the bounds should be reduced by 40 percent. However, adjustment is not required if there is a zero gap.

2- The monetary policy stance: with a contractionary monetary policy where interest rate is at the lower bound, both bounds of the range should be increased by 30 percent. However, if the monetary policy is constrained due to other reasons the adjustment is between 0 and 30 percent.

Scaling the bounds range up or down in equation (1)

$$
M=M_{N T} *(1+\text { Cycle }) *(1+\text { Mon })
$$

where $M$ is the multiplier, $M_{N T}$ is the "normal times" multiplier derived from stage 1, Mon is the monetary policy stance factor ranging from 0 to 0.3 . Then, the cyclical factor Cycle is ranging from -0.4 to +0.6 . 
It should be noted that the "Bucket approach" provides estimates for the first-year multiplier. Based on empirical literature findings, the multiplier converges to zero over five years and likely to record a higher value than the first year by almost 10 to 30 percent in the second year (Batini et al., 2014b). Deskar-Škrbić and Šimović (2015) employed the 'Bucket approach' to determine the factors that affect the size of fiscal multipliers in Western Balkan economies (Croatia, Slovenia and Serbia). They found that fiscal multipliers are small in magnitude based on key structural characteristics for the selected countries which are small open economies, with relatively rigid labor markets, strong automatic stabilizers, reasonable level of public debt and tight monetary policy. Afterwards, they confirm their findings through using the SVAR approach.

\section{Applying the Bucket Approach to Egypt}

1- Trade Openness: Total imports and final private consumption (a proxy for domestic demand) data are driven from the Central Bank of Egypt (CBE). The ratio of imports to domestic demand is shown in table (4).

TABLE (4) The Ratio of Imports to Domestic
Demand
\begin{tabular}{|lccccc}
\hline $\mathbf{2 0 1 2} / \mathbf{1 3}$ & $\mathbf{2 0 1 3} / \mathbf{1 4}$ & $\mathbf{2 0 1 4} / \mathbf{1 5}$ & $\mathbf{2 0 1 5} / \mathbf{1 6}$ & $\mathbf{2 0 1 6 / 1 7}$ & $\mathbf{2 0 1 7 / 1 8}$ \\
\hline 76.7 & 68.1 & 60.9 & 51.0 & 38.6 & 33.3 \\
\hline
\end{tabular}

Source: Author's Calculations

Hence, Egypt is not considered a relatively closed economy.

2- Labor Market Rigidities: According to Selwaness and Zaki (2015), Egypt's score level of labor market rigidity is estimated to be 1.5 based on labor market rigidity index (LAMRIG) ${ }^{(1)}$ estimated by the World Bank. LAMRIG index contains from 0 to 3 scaled index, with the highest score showing the most restrictive labor market such as Bahrain and Syria (2.5), followed by Tunisia and Libya (2.0), then Egypt, Oman, Morocco (1.5). Thus, the labor market in Egypt is considered a restrictive market with moderate level based on LAMRIG index. Labor laws in Egypt are mainly perceived as a major obstacle for employment creation and entrepreneurship development. In addition, according to the World Competitiveness Report, labor market is relatively rigid if the Labor market efficiency indicator is equal or below 4 on the scale 1-7. In the labor market efficiency index, Egypt had a score of 3.22, which indicates that its labor market is relatively rigid.

3- Size of Automatic Stabilizers: The ratio of total public spending to nominal GDP is a proxy for automatic stabilizers. With a CBE data for $2016 / 17$ and $2017 / 18$, the ratios are 0.30 and 0.28 respectively. Hence, automatic stabilizers are considered small.

4- Exchange Rate Regime:Fiscal policy are more effective under the fixed exchange rate. Since 2005, the exchange rate system was classified as managed floating regime for most of the period under study. Moreover, since November 2016, the CBE announced adopting a flexible exchange rate regime. This, in turn, may reduce the effectiveness of fiscal policy.

5- Level of Public Debt: Calculating the ratio of gross domestic debt to nominal GDP yields $91 \%$ in 2017, which is higher than the safe level.

Following the 'bucket approach', a value of 1 is assigned to the factors that imply a higher fiscal multiplier, or otherwise a value of 0 . The estimates in Egypt is shown in table (5).

Thus, the total score of 2 derived from table (5) indicates that Egypt has low fiscal multipliers. However, specific factors in the country must be taken into consideration through scaling the multiplier up or down depending on the conjectural factors.

\begin{tabular}{|c|c|}
\hline \multicolumn{2}{|c|}{ Structural Characteristics Assessment } \\
\hline Trade openness & 0 \\
\hline High Labor market rigidity & 1 \\
\hline Small Automatic stabilizers & 1 \\
\hline $\begin{array}{l}\text { Fixed or Quasi-fixed } \\
\text { Exchange Rate Regime }\end{array}$ & 0 \\
\hline Low/Safe Public debt level & 0 \\
\hline Total Score & 2 \\
\hline
\end{tabular}

Source: Author's Calculations

(1) The Labor Market Rigidity Index measures the rigidity of employment conditions for each country at various points in time from (1950 to 2000-04). This index includes 145 countries. It captures a number of important institutional dimensions in the labor market, namely rigidity of alternative employment contracts, rigidity of hours, cost of firing workers and dismissal procedures. Each of the four dimensions has a number of sub-indices. 


\section{Estimating the Business Cycle of Egypt}

The Hodrick-Prescott (HP) filter has become a conventional statistical method to measure potential output. This method minimizes the sum of squared distances between potential and actual output at any point in time, subject to a restriction on the variation of potential output. The restriction parameter $\lambda$ smooths the series of potential output when tracing the significance of cyclical shocks to output relative to shocks to output trend. Figure (1) illustrates the output gaps estimated by the HP filter to the quarterly real GDP series across 2005 - 2017. The suggested restriction parameter $\lambda$ is set at 1600 for quarterly data.

Hodrick-Prescott Filter (lambda=1600)

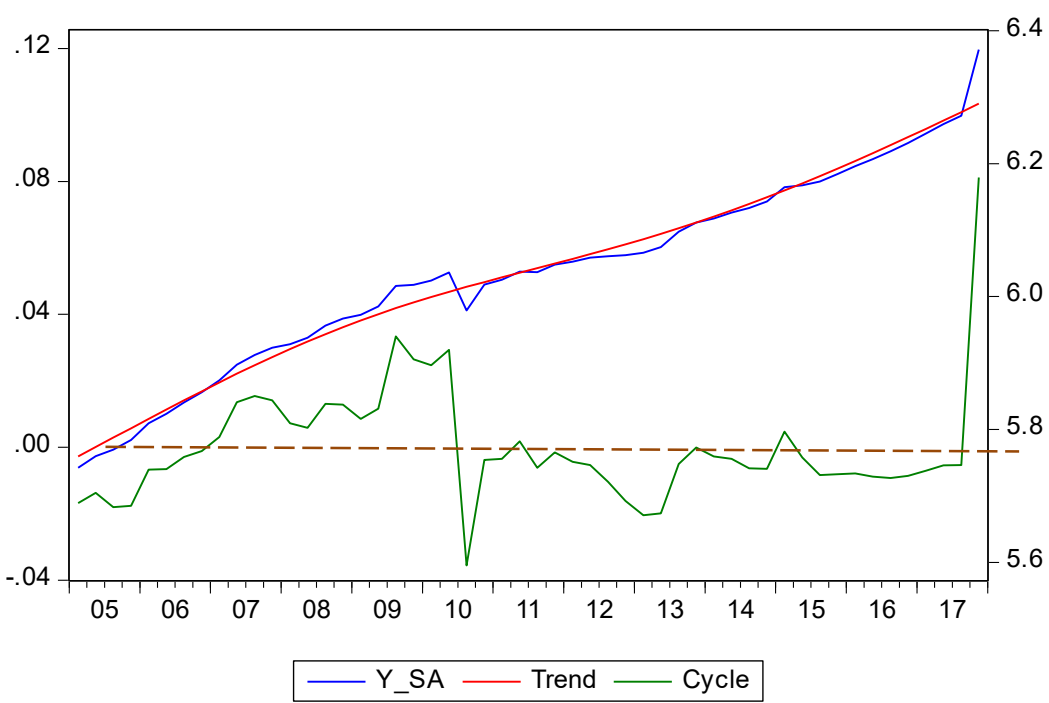

Note: The Graph is Generated for HP-Prescott Filter Using E-views 8 Software.

FIGURE 1: The output gaps over the period $(2005-2017)$

The results obtained from figure (1) show negative output gap as indicated by the cycle trend that extends across 2010:1 -2017:3. The recessionary period are 8 years which equals almost $60 \%$ of the overall period. Hence, the bounds should be scaled up by $36 \%$ (60\% multiplied by the percentage of the recession period).

\section{Degree of Monetary Accommodation to Fiscal Shocks:}

Egypt's interest rate has not reached the zero lower bound. Despite several CBE rate cut, the real policy rate of almost $9.45 \%$ is still considered attractive because it remains higher relative to Egypt's global peers such as Ukraine (9\%) and Turkey (7.2\%) (Egypt Country Risk Report, Q1 2020). Therefore, the multiplier's range could be adjusted between 0 and 30 percent. So, the multiplier range will be scaled up by 0.15 . Adjusting the multiplier's range as per equation (1) is shown in table (6):

\section{The Lower Bound:}

$$
\begin{array}{ll}
- & M=M_{N T} \times(1+\text { Cycle }) \times(1+\text { Mon }) \\
- & M=0.1 \times(1+0.36) \times(1+0.15) \\
- & M=0.1 \times(1.36) \times(1.15)=0.16
\end{array}
$$

TABLE (6) Modification of the Multiplier Range

\section{The Upper Bound:}

$$
\begin{array}{ll}
\text { - } & M=0.3 \times(1+0.36) \times(1+0.15) \\
\text { - } & M=0.3 \times(1.36) \times(1.15)=0.50
\end{array}
$$

\begin{tabular}{lccc}
\hline Country Score & $\begin{array}{c}\text { Multiplier } \\
\text { Range }\end{array}$ & $\begin{array}{c}\text { Muliplier After Scaling } \\
\text { Up / Down }\end{array}$ \\
\hline Egypt 2 & $\begin{array}{c}\text { Low } \\
(0.1-0.3)\end{array}$ & $0.16-0.50$ \\
\hline
\end{tabular}

\section{Methodology}

\section{Data}

The SVAR model includes four variables across 2005/06 - 2017/18 with quarterly data, namely government spending $\left(G_{t}\right)$, tax revenues $\left(R_{t}\right)$, output $\left(Y_{t}\right)$ and interest rate $\left(i_{t}\right)$. Two fiscal instruments are included 
in this model because the size of fiscal multiplier is not only affected by the behavior of government spending but also the tax revenues response. In addition, interest rate is included to control for the monetary policy since the interaction between both policies matters in determining the magnitude of fiscal multiplier. Data for the government expenditure, the interest rate and tax revenues are collected from the Central Bank of Egypt (CBE), and for output, the GDP deflator from the Ministry of Planning and Economic Development.

Real interest rate is obtained by subtracting inflation from nominal interest rate. The data are in real terms and in natural logarithmic forms except for real interest rate. Also, all data are seasonally adjusted using the X12 method in E-views.

\section{The SVAR Model}

Consider the following Structural VAR system:

$$
A(0) X_{t}=\mu+A(L) X_{t-p}+B e_{t}
$$

where $A(0)$ is the matrix of contemporaneous interactions, $X_{t}=[G, R, Y, I]>$ is $(n \times 1)$ vector containing each of the $n$ variables included in the VAR, $A(L)$ is pth order matrix polynomial in the lag operator $L^{(1)}, \mu$ is a vector of constants and $e_{t}=\left[e^{g}, e^{r}, e^{y}, e^{i}\right]$, is a vector of structural innovations which are assumed to be contemporaneously correlated but not autocorrelated, since: $E\left(e_{t}\right)=0, E\left(e_{t} e_{t}^{\prime}\right)=\sum, E\left(e_{t} e_{s}^{\prime}\right)=0$ for $t \neq s$

The starting point is to obtain the reduced-form by multiplying equation (2) by $A(0)^{-1}$ :

$$
X_{t}=\mu^{*}+A(L)^{*} X_{t-1}+\varepsilon_{t}
$$

where:

$$
\text { - } \mu^{*}=\mathrm{A}(0)^{-1} \mu \quad-\mathrm{A}(\mathrm{L})^{*}=\mathrm{A}(0)^{-1} \mathrm{~A}(\mathrm{~L}) \quad-\varepsilon_{\mathrm{t}}=\mathrm{A}(0)^{-1} \mathrm{Be}_{\mathrm{t}}
$$

From equation (3), it appears that the reduced-form residuals $\left(\varepsilon_{t}\right)$ is a vector of uncorrelated and normally distributed but contemporaneously correlated with each other, which impedes getting a precise economic interpretation The relation between structural shocks and reduced-form shocks is:

$$
\mathrm{A}(0) \varepsilon_{\mathrm{t}}=\mathrm{Be}_{\mathrm{t}}
$$

The VAR analysis needs the structural innovations $\left(\mathrm{e}_{\mathrm{t}}\right)$ not the reduced-form residuals $\left(\varepsilon_{\mathrm{r}}\right)$. So, identification of the dynamic effects of the unobservable exogenous shocks is necessary through imposing restrictions on the VAR representation.

\section{The SVAR Identification}

The contemporaneous restrictions identification method is employed based on economic theory in which the shocks are assumed to have temporary effects on the variables. Actually, high frequency enables this identification process because policy makers cannot respond to changes in economic circumstances within a quarter. Such restriction depends on actual observations and available information about the delayed response of particular variable to disturbances.

Much of the SVAR literature imposes this type of restrictions, with which medium to long run relationships are left unrestricted, whereas more general restrictions are imposed on contemporaneous relationships among variables. Actually, quarterly data frequency has a significance role in the identification process that is because policy makers cannot respond to changes in the economic circumstances within a quarter. Contemporaneous restrictions on the influences of the shocks on the variables included in the model have been traditionally obtained through imposing arbitrary zero restrictions. Moreover, such restriction is rela-

(1) The lag operator (L) works as follows: $L y_{t}=y_{t-1}, L^{2} y_{t}=L y_{t-1}=y_{t-2}, \ldots ., L^{n} y_{t}=y_{t-n}$.

The lag polynomial $A(L)$ takes the general form $A(L)=A_{1} L+A_{2} L^{2}+\ldots . .+A_{p} L^{p}$. 
tively easy to evaluate and argue about since it depends on actual observations and available information about the delayed response of particular variable to disturbances.

According to Amisano and Giannini (1997) and Giannini (1992), identification is obtained through imposing restrictions in the $A B$ model:

\section{ABModel: Given That the Reduced-form SVAR Could be Represented As:}

$$
\mathrm{A}(\mathrm{L}) \mathrm{y}_{\mathrm{t}}=\varepsilon_{\mathrm{t}}, \varepsilon_{\mathrm{t}} \sim\left(0, \sum \varepsilon\right)
$$

Consider $A$ and $B$ two $(n \times n)$ invertible matrices such that:

- $\quad A A(L) y_{t}=A \varepsilon_{t}$

- $A \varepsilon_{\mathrm{t}}=B e_{\mathrm{t}}, \mathrm{e}_{\mathrm{t}} \sim\left(0, \mathrm{I}_{\mathrm{n}}\right)$

Then:

- $\quad \varepsilon_{\mathrm{t}}=\mathrm{A}^{-1} \mathrm{Be}_{\mathrm{t}}$

Given that $\sum_{\mathrm{e}}=\mathrm{I}_{\mathrm{n}^{\prime}}$ the variance-covariance matrix of the reduced-form residuals is obtained by:

- $\quad \sum_{\varepsilon}=\mathrm{A}^{-1} \mathrm{BB}^{\prime}\left[\mathrm{A}^{-1}\right]$ >

In this most general type of SVAR, restrictions can be placed on the two matrices A and B. It should be noted that the A matrix enables to model explicitly the contemporaneous relationship among endogenous variables, while the $B$ matrix represents the effect of orthonormal shocks on the equations of the system .

\section{Applying the AB Model to Identify the SVAR Yields:}

- $A \varepsilon_{t}=\mathrm{Be}_{\mathrm{t}}$

In matrix notation:

$$
=\left[\begin{array}{cccc}
1 & a_{12} & a_{13} & a_{14} \\
a_{21} & 1 & a_{23} & a_{24} \\
a_{31} & a_{32} & 1 & a_{34} \\
a_{41} & a_{42} & a_{43} & 1
\end{array}\right]\left[\begin{array}{c}
\varepsilon^{g_{t}} \\
\varepsilon^{r_{t}} \\
\varepsilon^{y_{t}} \\
\varepsilon_{t}^{i}
\end{array}\right] \quad\left[\begin{array}{llll}
b_{11} & 0 & 0 & 0 \\
0 & b_{22} & 0 & 0 \\
0 & 0 & b_{33} & 0 \\
0 & 0 & 0 & b_{44}
\end{array}\right]\left[\begin{array}{c}
e^{g_{t}} \\
e^{r_{t}} \\
e^{y_{t}} \\
e^{i_{t}}
\end{array}\right]
$$

The minimum number of contemporaneous restrictions required in the case of $A B$ model is $K^{2}+K(K-$ $1) / 2$, to be imposed on the matrices $A(0)$ and $B$, for exact identification of a structural model from an estimated VAR with K-variables and p-lags (McCoy,1997 and Enders, 2010). Thus, the identification of the structural shocks proceeds with 12 zero restrictions on $B$ and six contemporaneous restrictions on $A(0)$ such that $\mathrm{a}_{13}=\mathrm{a}_{23}=\mathrm{a}_{14}=\mathrm{a}_{24}=\mathrm{a}_{12}=\mathrm{a}_{34}=0$, where the assumptions are:

- Government spending and tax revenues responses to output take longer than the quarter. Therefore, the coefficients $\left(\mathrm{a}_{13}\right)$ and $\left(\mathrm{a}_{23}\right)$ are set to zero.

- Government spending and tax revenues responses to real interest rate are restricted to zero within a quarter $\left(\mathrm{a}_{14^{\prime}}, \mathrm{a}_{24}\right)$.

- Tax revenues react to shocks in government expenditure but not the opposite direction $\left(\mathrm{a}_{12}\right)$ because tax collection procedures are annually based.

- Real interest rate effect on output $\left(\mathrm{a}_{34}\right)$ is restricted within the same quarter. 


\section{Testing for Stationarity}

The Augmented Dickey-Fuller (ADF) test is conducted to examine the integration properties of the time series. The results confirm the rejection of a null hypothesis of a unit root at $1 \%$ significance level for three variables namely government expenditure, tax revenues and real interest rate, while the null hypothesis is accepted for the real GDP, which becomes stationary in the first level.

\section{The Choice of Lag Length}

The choice of the appropriate lag length is crucial to eliminate the auto correlations in the error terms while capturing properly the dynamic interrelationship among the variables in the SVAR model. The optimal lag length is 2 lags according to three tests the sequential modified LR test statistic (each test at 5\% level) (LR), Final Prediction error (FPE) and Hannan-Quinn information criterion (HQ). This optimal lag length satisfies stability of the VAR, which maintains that the model is invertible in order to ensure that the vector-moving average (VMA) representation is obtainable.

\section{Empirical Results}

The SVAR model is just identified using JMulti and E-views softwares. The estimated structural coefficients in the $A$ and $B$ matrices are shown in table (8).

It is worth noting that the contemporaneous effect of government spending on real output proves to be positive and significant unlike the tax revenues. Also, the contemporaneous effect of tax revenues on real interest rate proves to be significant.

\section{The Impulse Response Functions (IRFs)}

The impulse response paths are reported for a horizon of 20 quarters. The confidence intervals of the impulse responses are calculated by a Bootstrap method to evaluate the statistical significance of impulse responses. The estimated responses correspond to one standard deviation error in impulse response with 95\% bootstrap confidence interval based on 1000 bootstrap replica-

TABLE (8) The Estimated Structural Coefficients of the Model

\begin{tabular}{|c|c|c|c|c|}
\hline \multicolumn{5}{|c|}{ Estimated short-run impact } \\
\hline & G & $\mathbf{R}$ & $\mathrm{Y}$ & i \\
\hline G & 1.0000 & 0.0000 & 0.0000 & 0.0000 \\
\hline $\mathrm{R}$ & $-0.1217[0.7159]$ & 1.0000 & 0.0000 & 0.0000 \\
\hline $\mathrm{Y}$ & $\begin{array}{c}0.0361 \\
{[2.4228]} \\
\end{array}$ & $\begin{array}{l}-0.0181 \\
{[-1.448]} \\
\end{array}$ & 1.0000 & 0.0000 \\
\hline $\mathrm{i}$ & $\begin{array}{c}-0.0381 \\
{[-0.0174]}\end{array}$ & $\begin{array}{c}3.6374 \\
{[2.01614]} \\
\end{array}$ & $\begin{array}{l}-12.8142 \\
{[-0.6466]}\end{array}$ & 1.0000 \\
\hline \multicolumn{5}{|c|}{ Estimated B matrix } \\
\hline & $\mathbf{G}$ & $\mathbf{R}$ & $\mathrm{Y}$ & $\mathrm{i}$ \\
\hline G & $0.1580[9.875]$ & 0.0000 & 0.0000 & 0.0000 \\
\hline $\mathrm{R}$ & 0.0000 & $\begin{array}{c}0.1881 \\
{[9.9]} \\
\end{array}$ & 0.0000 & 0.0000 \\
\hline Y & 0.0000 & 0.0000 & $\begin{array}{l}0.0164 \\
{[9.647]}\end{array}$ & 0.0000 \\
\hline $\mathrm{i}$ & 0.0000 & 0.0000 & 0.0000 & $\begin{array}{r}2.2742 \\
{[9.9007}\end{array}$ \\
\hline
\end{tabular}

Source: Author's Calculations
TABLE (7) Results of the Unit Root Test

Variables t-statistic Order of Integration

\begin{tabular}{ccc}
\hline$G$ & -4.25202 & $\mathrm{I}(0)$ \\
\hline $\mathrm{r}$ & -6.06775 & $\mathrm{I}(0)$ \\
\hline $\mathrm{Y}$ & $-5.95895^{* * *}$ & $\mathrm{I}(1)$ \\
\hline $\mathrm{I}$ & $-3.48919^{* *}$ & $\mathrm{I}(0)$ \\
\hline
\end{tabular}

Notes: 1- The ADF test was conducted by including the intercept term. However, for the test of $\mathrm{G}$ a trend and intercept were included. 2- Optimal lag length was chosen by Schwarz Information Criteria (SIC).

3- Critical values were obtained from Mackinon (1991), where the critical values are -3.5683 at $1 \%,-2.921175$ at $5 \%$ and -2.598551 at $10 \%$ significance levels respectively.

4- *** indicate that the null hypothesis of the existence of unit root is rejected at $1 \%$ significance levels.

tions. Efron and Hall Percentile confidence interval method is used (Efron \& Tibshirani, 1993). The IRFs illustrate the relations among the variables which prove to be consistent with the economic theory.

\section{Effects of Fiscal Policy:}

Our main interest in this paper is to investigate the effect of fiscal multipliers on real output. The IRFs of government spending and tax revenues on real output are illustrated in figure (2). 
$G->Y$

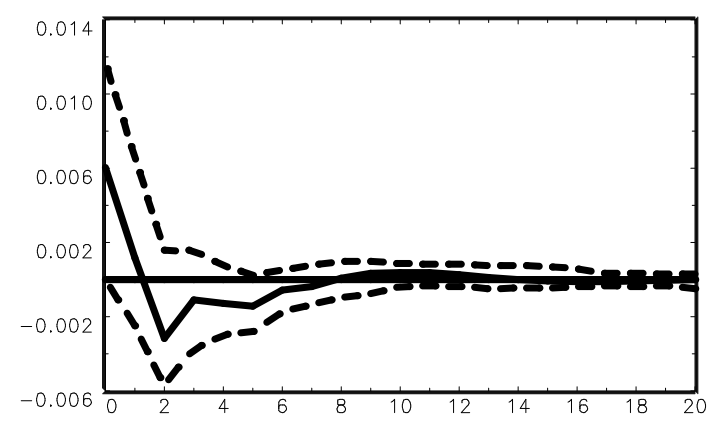

$r->Y$

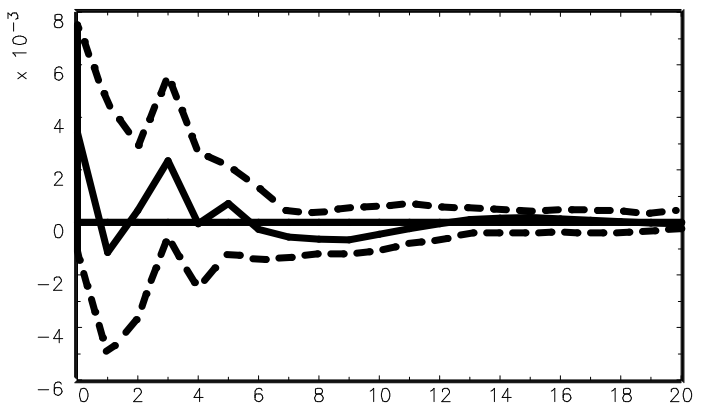

FIGURE 2: Government Spending and Tax Revenues Multipliers

Regarding the effect of fiscal policy shocks, the IRFs demonstrate that the effect of fiscal policy shocks on real output is positive but short-lived effect. A one standard deviation positive shock of government expenditure, which is equivalent to 16 units, increases the GDP growth rate $(Y)$. This significant increase lasts for 2 quarters with an amount of 0.6 unit before it dies out after the second quarter. The impact of tax multiplier on GDP is positive which is inconsistent with economic theory and other empirical literature. A one standard deviation positive shock to tax revenue that equals 18 units increases output initially by 0.3 , this increase is followed by second minimal increases in the third and fourth quarters of 0.05 and 0.2 respectively before the effect dies out. However, it should be noted that such effect was insignificant as illustrated in table (8). Comparing the impact of different fiscal policy instruments, the government expenditure is a much more effective tool than the tax revenues.

Alternatively, the cumulative responses of output to fiscal policy instruments reveal the total increase in GDP due to fiscal policy shocks during the period. The accumulated responses of real output to different tools of fiscal policy are shown in figure (3). A positive government expenditure shock initially increases output by 0.6 , followed by a further increase in the first quarter by 0.72 , which represents the peak multiplier, before it gradually declines. Likewise, the effect of tax revenues shocks on output is an initial increase by 0.34 , followed by small increases that reach a peak multiplier of 0.58 in the fifth quarter before it gradually dies out.
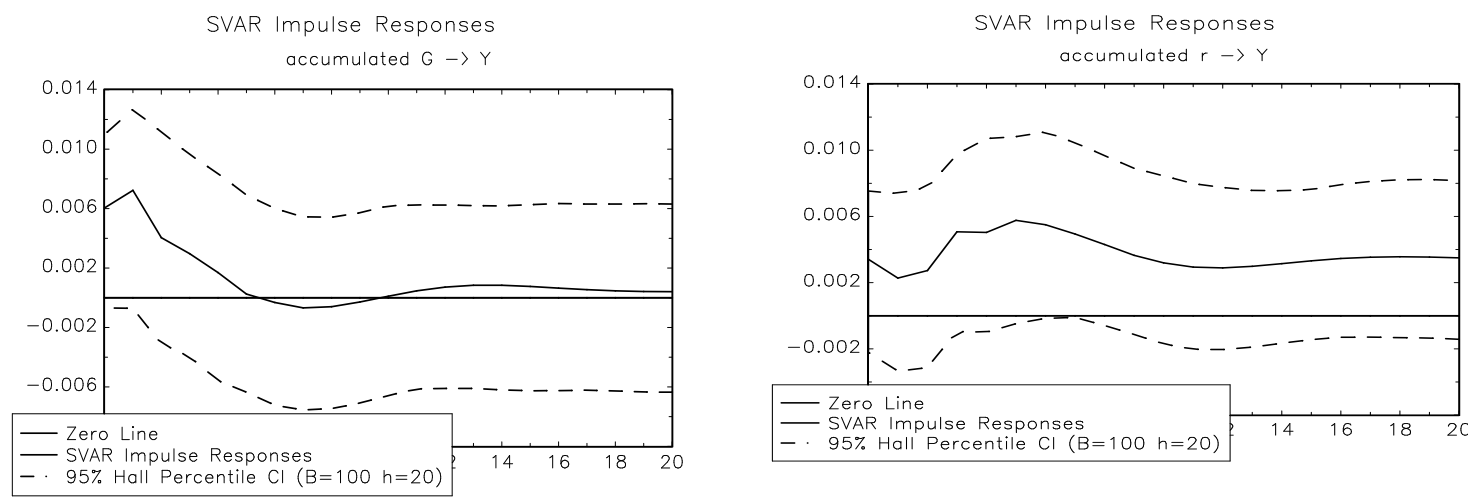

FIGURE 3: The Accumulated Responses of Real Output to Fiscal Policy Shocks

\section{Procyclicality of Fiscal Policy:}

As it is mostly the case in many developing countries, there is a strong evidence of procyclical fiscal policy with government spending in Egypt (Figure (4)). 

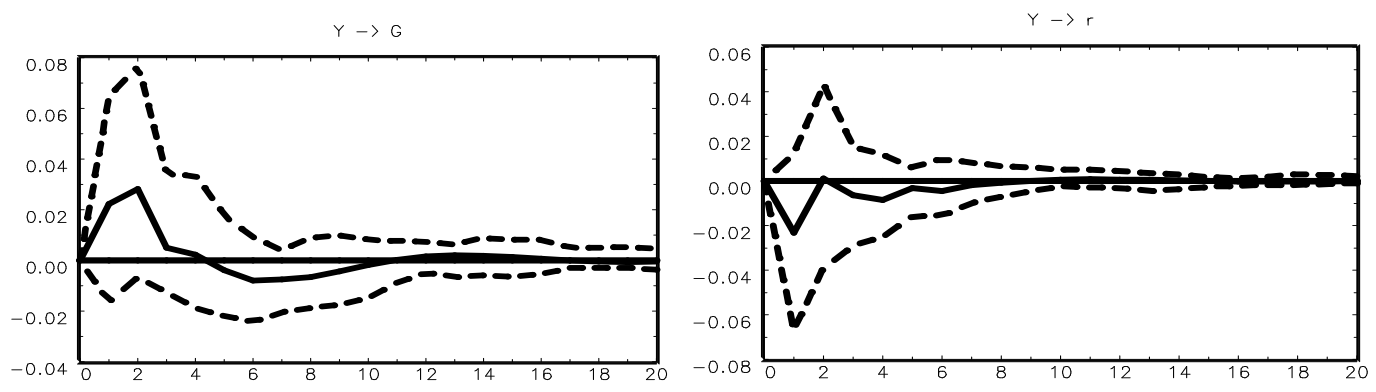

FIGURE 4: The Effect of Real Output on Fiscal Policy Instruments

According to Alesina and Tabelini (2005), many developing countries follow procyclical fiscal policy because of the credit constrains. During recession, many developing countries have to cut spending or lower deficits because they cannot borrow or they have to accept high interest rate and the opposite is true during booms. Moreover, they added a political factor that entails that voters cannot trust the corrupted government with available resources, so they demand a decrease in taxes or increase in expenditures when positive shocks hit the economy to maintain resources from being wasted.

\section{The Effect of Monetary Policy Tightening:}

Figure (5) illustrates that a positive shock to real interest rate decreases growth rate of GDP for almost 3 quarters. This decrease is a result of the decline in investment following a rise in interest rate. The tax revenues decline, as well, slightly in the first year as a result of an increase in interest rate that is reflected on a decline in investment. Also, the effect of interest rate on government spending is negative and decreases the government spending by 5 in the first year. This impact could be explained by an increase in borrowing costs of the government.
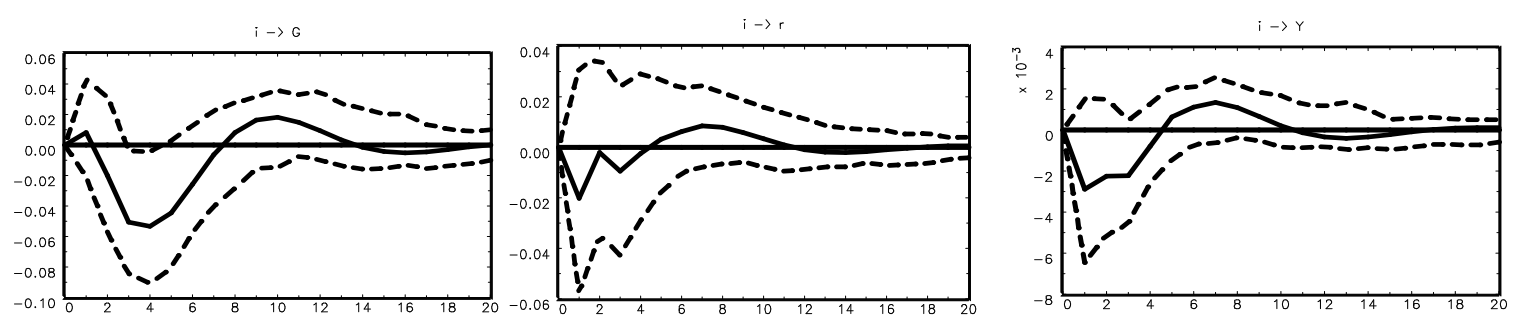

FIGURE 5: The Effect of Interest Rate on the Other Variables

\section{The Effect on Real Interest Rate:}

An increase in government spending drives real interest rate up for almost 4 quarters before the effect fades. A gradual increase that reaches a peak of 0.6 in the $3^{\text {rd }}$ and $4^{\text {th }}$ quarters. This could be explained by two factors; first, the central bank's policy to increase interest rate to contain the inflationary pressures associated with the increase in government spending. Second, an increase in government spending may raise the risk premium, thereby increasing the interest rate. It should be noted that the increase in interest rate may partly offset the expansionary effect of fiscal policy.

Being consistent with economic theories, an increase in GDP will increase the demand for money sufficiently to purchase the new GDP. This, in turn, will increase the interest rate level in the country. However, a positive shock to tax revenues decreases the real interest rate for almost one year before it increases slightly in the second year. An increase in tax revenues could provide available source of finance to the government spending instead of the debt- issuance which puts upward pressure on interest rate. 

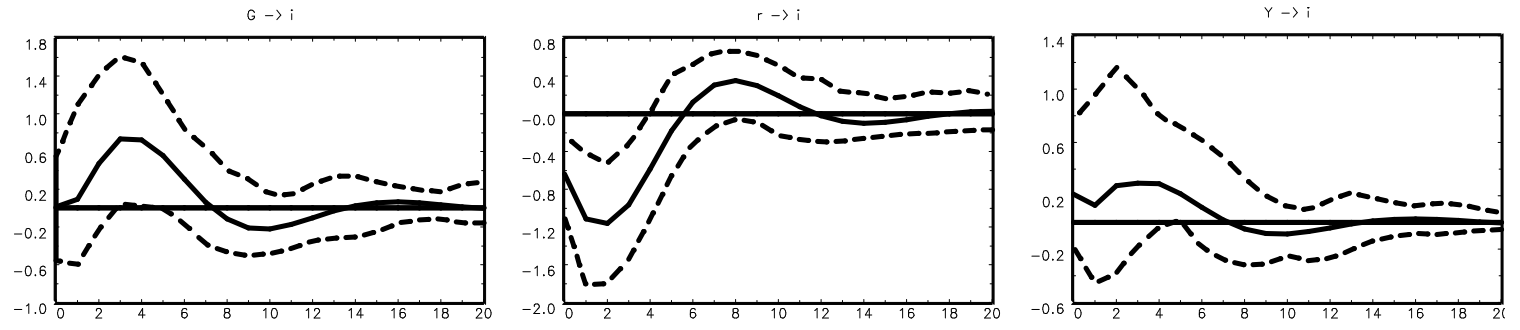

FIGURE 6: The Effect of Other Macroeconomic Variables on Interest Rate

\section{The Interaction between Fiscal Policy Instruments:}

An increase in tax revenues will encourage government spending as an available source of finance after a lag of 2 quarters. Such increase in government spending will last for one year and half before it disappears. Likewise, a positive shock to government spending increases tax revenues for a short term of one quarter before it dies out. An expansionary fiscal policy is associated with higher tax revenues through one of two channels: (i) An increase in government spending may raise GDP; which, in turn, stimulates private spending and hence tax revenues and (ii) the government may raise taxes so as to finance its spending and lower the budget deficits. Nevertheless, tax revenues are insufficient to finance the Egyptian government expenditure; which results in accumulating public debt.
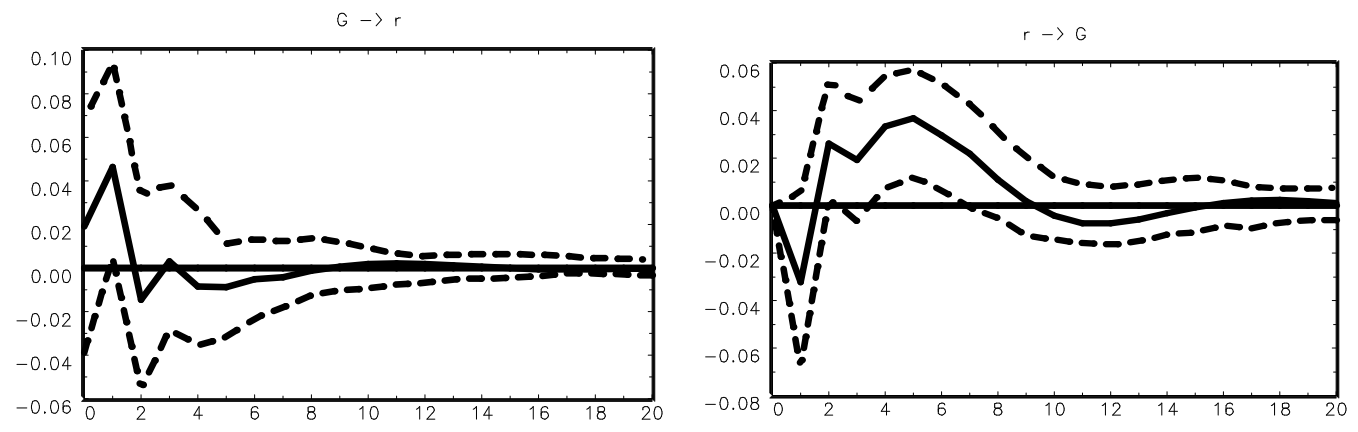

FIGURE 7: The Interaction Between Tax Revenues and Government Spending

\section{The Forecast Error Variance Decompositions (FEVDCs)}

The forecast error variance decomposition (FEVDCs) for each variable reveals the proportion of the movement in this variable due to its own shock versus the shocks in other variables at a given horizon. Results are reported in table (9) at various forecast error horizons over a period of 7 years.

Movement in the real output is mainly driven by its own shocks over the forecast horizons. Shocks to government expenditure are the second source of variation in real output with a percentage of $14 \%$ after the first year. With regards to the interest rate, it is mainly driven by its own shocks in the short-run, while the tax revenues shocks have the highest impact on interest rate. Revenues become the second source of variation from the fourth quarter with a percentage of $20 \%$.

The variance decomposition reveals that the government expenditure is mainly driven by its own shock all over the forecast horizons. Shocks to the real interest rate explain a portion $16-17 \%$ of the movement in government expenditures starting from the second year. Shocks to tax revenues explain a small portion of $11 \%$ of the movement in government expenditure from the second year. As for the tax revenues, it is mainly driven by its own shocks all over the forecast horizon. 
TABLE (9) The Forecast Error Variance Decompositions

Proportions of forecast error in G Accounted for by:

\begin{tabular}{ccccc}
\hline Forecast Horizon (Quarters) & $\mathrm{G}$ & $\mathrm{R}$ & $\mathrm{Y}$ & $\mathrm{I}$ \\
\hline 1 & 1.00 & 0.00 & 0.00 & 0.00 \\
\hline 2 & 0.95 & 0.03 & 0.01 & 0.01 \\
\hline 4 & 0.85 & 0.05 & 0.03 & 0.07 \\
\hline 6 & 0.73 & 0.08 & 0.03 & 0.16 \\
\hline 8 & 0.70 & 0.11 & 0.03 & 0.16 \\
\hline 10 & 0.70 & 0.11 & 0.03 & 0.16 \\
\hline 14 & 0.69 & 0.11 & 0.03 & 0.17 \\
\hline 20 & 0.69 & 0.11 & 0.03 & 0.17 \\
\hline 28 & 0.69 & 0.11 & 0.03 & 0.17
\end{tabular}

Proportions of forecast error in R Accounted for by:

\begin{tabular}{ccccc}
\hline Forecast Horizon (Quarters) & $\mathrm{G}$ & $\mathrm{R}$ & $\mathrm{Y}$ & $\mathrm{I}$ \\
\hline 1 & 0.01 & 0.99 & 0.00 & 0.00 \\
\hline 2 & 0.06 & 0.91 & 0.01 & 0.02 \\
\hline 4 & 0.06 & 0.91 & 0.01 & 0.02 \\
\hline 6 & 0.06 & 0.91 & 0.01 & 0.02 \\
\hline 8 & 0.06 & 0.91 & 0.01 & 0.02 \\
\hline 10 & 0.06 & 0.91 & 0.01 & 0.02 \\
\hline 14 & 0.06 & 0.91 & 0.01 & 0.02 \\
\hline 20 & 0.06 & 0.91 & 0.01 & 0.02 \\
\hline 28 & 0.06 & 0.91 & 0.01 & 0.02 \\
\hline
\end{tabular}

Source: Author's Calculation
Proportions of forecast error in $\mathrm{Y}$ Accounted for by:

\begin{tabular}{ccccc}
\hline Forecast Horizon (Quarters) & $\mathrm{G}$ & $\mathrm{R}$ & $\mathrm{Y}$ & $\mathrm{I}$ \\
\hline 1 & 0.11 & 0.04 & 0.85 & 0.00 \\
\hline 2 & 0.11 & 0.04 & 0.83 & 0.02 \\
\hline 4 & 0.13 & 0.05 & 0.77 & 0.05 \\
\hline 6 & 0.14 & 0.05 & 0.76 & 0.05 \\
\hline 8 & 0.14 & 0.05 & 0.76 & 0.05 \\
\hline 10 & 0.14 & 0.05 & 0.75 & 0.06 \\
\hline 14 & 0.14 & 0.05 & 0.75 & 0.06 \\
\hline 20 & 0.14 & 0.05 & 0.75 & 0.06 \\
\hline 28 & 0.14 & 0.05 & 0.75 & 0.06 \\
\hline
\end{tabular}

Proportions of forecast error in i Accounted for by:

\begin{tabular}{ccccc}
\hline Forecast Horizon (Quarters) & $\mathrm{G}$ & $\mathrm{R}$ & $\mathrm{Y}$ & $\mathrm{I}$ \\
\hline 1 & 0.00 & 0.07 & 0.01 & 0.92 \\
\hline 2 & 0.00 & 0.13 & 0.00 & 0.87 \\
\hline 4 & 0.04 & 0.20 & 0.01 & 0.75 \\
\hline 6 & 0.08 & 0.20 & 0.02 & 0.70 \\
\hline 8 & 0.08 & 0.20 & 0.02 & 0.70 \\
\hline 10 & 0.08 & 0.20 & 0.02 & 0.70 \\
\hline 14 & 0.08 & 0.20 & 0.02 & 0.70 \\
\hline 20 & 0.08 & 0.20 & 0.02 & 0.70 \\
\hline 28 & 0.08 & 0.20 & 0.02 & 0.70 \\
\hline
\end{tabular}

\section{Discussion}

The empirical and non-empirical methods applied in this paper concluded that contrary to the Keynesian view, the multiplier effect is relatively small and short-lived in Egypt. Government expenditures prove to be significant and effective tool in the short-run compared to tax revenues. The small fiscal multiplier result is consistent with other studies; such as in Egypt (Hassan, 2007), Al-Nashar, S. (2017), Nafie and Atlam (2019), in Albania (Mançellari (2011)), Indonesia (Surjaningsih et al. (2012)), South Africa (Jooste et al. (2013)), the EMU (van Aarle et al. (2003)) and in 5 OECD countries (Perotti (2004)).

Investigating the reasons behind small fiscal multipliers, both theoretical and empirical evidence identify potential non-Keynesian effects ${ }^{(1)}$. Nicoletti (1988) found that the Ricardian equivalence (which implies a zero fiscal multiplier) holds in some high-debt countries such as Italy and Belgium. Moreover, Denis and Quinet (2002) investigated the non-Keynesian effects using a panel-data approach. They concluded that the non-Keynesian effects affect the size of fiscal multiplier but not the sign. These effects exist between the mid-eighties and the late nineties in small open economies and Italy. They maintained that the effectiveness of discretionary fiscal policy can be impeded in countries with a rapidly growing debt to GDP ratio. This possibility of non-Keynesian effects has been raised by van Aarle et al. (2003). In their explanation of unexpected response of real output to a positive government spending shock in the United States and Japan, they maintained that the Keynesian effects of fiscal adjustments are outweighed by the non-keynesian effects.

Furthermore, Hemming et al. (2002) added a number of institutional features that are particularly relevant to the developing countries and cause a reduction in the fiscal multipliers such as: (i) long inside and outside lags: inside lags occur through the time the government takes to recognize the need to change the

(1) The non-Keynesian effects of fiscal policy arise from the new classical models that deal with the shortcomings of the Keynesian approach, particularly the lack of microeconomic foundations; such as rational expectations, Ricardian equivalence, interest rate risk premia and policy credibility and uncertainty. 
fiscal policy and to adopt appropriate measures, or outside lags are the necessary time for fiscal measures to materialize in the aggregate demand; (ii) the accessibility and cost of domestic or external financing, as well as lack of access to international capital markets, particularly in highly indebted developing countries determine the size of fiscal deficit. Thus, high fiscal deficit beyond satisfactory levels to finance it results in strong crowding out effects and (iii) some factors that complicate the fiscal policy implementation; such as poor tax administration, management of expenditure, governance problems, long lags influencing fiscal policy $^{(1)}$ and large deficit bias ${ }^{(2)}$.

It is worth noting that the duration of the effects of fiscal policy tools is very short in the case of Egypt. This could be explained by many factors namely; (i) the persistence of the fiscal shock; (ii) the type of fiscal instrument; and (iii) conjunctural factors such as the cyclical position and whether monetary policy responds to the fiscal shock (Batini et al., 2014a). Moreover, some other factors that contribute to lower size of fiscal multiplier are inefficiencies in public expenditure management and revenue administration, precautionary savings in a more uncertain environment and high degree of openness in a small economy (Batini et al., 2014b).

Hamr-Adams and Wong (2018) clarified some reasons behind a multiplier that is less than 1; namely (i) leakages resulting from the use of government spending to import from abroad, (ii) crowding out of the private sector when the economy is near capacity and expansionary fiscal policy creates upward pressure on interest rate, exchange rate and inflation rate, (iii) expansionary fiscal policy act as a substitute for private spending and (iv) Ricardian equivalence may hold when households respond to expansionary fiscal policy by increase their current savings based on their expectations of higher tax liabilities in the future.

The above discussion and the findings in the 'Bucket approach' shed light on some factors that contribute to the low size of fiscal multipliers. This, in turn, points to the fact that discretionary fiscal policy is ineffective in Egypt. Egypt is considered a small but open economy which reduces the multiplier effect through leakages, in addition to high ratio of public debt to GDP, inefficient public expenditure management and revenue administration, flexible exchange rate and the crowding-out effect of private sector.

\section{Conclusion}

This paper investigates the effect of fiscal policy in Egypt through measuring the fiscal multipliers with the two main instruments of fiscal policy; namely government expenditures and tax revenues. Towards this purpose, non-empirical and empirical methods have been utilized in this paper. With regards to the first method, the 'bucket approach' has been applied to deduce the size of fiscal multipliers. This approach was initially suggested by Batini et al. (2014a) particularly for countries that suffer from lack of data. This approach depends on certain economic characteristics that are believed to have a significant effect in determining the size of fiscal multiplier. The findings prove that the size of fiscal multiplier is low and ranges from 0.16 to 0.50 .

Considering the empirical approach, a structural VAR method is utilized over the period (2005/06 - 2017/18) using quarterly data. This high-frequency data enables identifying the SVAR model through imposing the contemporaneous restrictions. Such restrictions imply that specific shocks have deferred impacts on some of the variables. The model includes four variables in real terms, namely government expenditures, tax revenues, output and interest rate. The first three variables are in natural logarithm form.

(1) Given the weak automatic stabilizers in the developing countries, inside lags are possibly longer (Tanzi, 1986).

(2) The deficit Bias is caused by many political factors, for instance debt accumulation may be utilized to reduce the fiscal room for future governments or policy makers, postponed fiscal consolidations due to conflicts concerning the sharing of costs among different groups and existing budget institutions operate in a way that causes permanent high spending. 
Obtained results prove that the contemporaneous effect of government spending on real output is positive and significant unlike the tax revenues. The impulse response functions demonstrate that the effect of government spending shocks on real output is positive but short-lived effect. The size of government expenditures multiplier equals an amount of 0.6 followed by a further increase in the first quarter by 0.72 units, which represents the peak multiplier, before it dies out after the second quarter. This confirms a limited Keynesian demand push. However, the tax revenues multiplier is found to have a positive but insignificant effect that it is estimated at 0.3. which is not in line with Keynesian theory. Comparing the impact of different fiscal policy instruments, the government expenditures instrument is much more effective than the tax revenues.

As it is mostly the case in many developing countries, there is a strong evidence of pro-cyclical fiscal policy with government spending in Egypt. Other effects were of great interest and come in line with theory. Tightening the monetary policy has a negative effect on real GDP and tax revenues through its negative effect on the investment channel. Also, government spending decreases because of the increase in borrowing costs of the government.

The effect of all macroeconomic indicators on interest rate is of great interest. An increase in government spending drives real interest rate up for almost 4 quarters before the effect fades. One of the reasons is the central bank's policy to increase interest rate to contain the inflationary pressures associated with the increase in government spending. Also, an increase in GDP will increase the demand for money sufficiently to purchase the new GDP. This, in turn, will increase the interest rate level in the country. However, a positive shock to tax revenues decreases the real interest rate for almost one year before it increases slightly in the second year. An increase in tax revenues could provide available source of finance to the government spending instead of the debt- issuance which puts upward pressure on interest rate. Actually, revenue shocks have the greatest impact on interest rate after its own shocks based on the forecast error variance decomposition.

The findings shed light on some factors that contribute to lower the size of fiscal multipliers. This, in turn, points to the fact that discretionary fiscal policy is ineffective in Egypt. Egypt is considered a small but open economy, this, in turn, reduces the multiplier effect through leakages. In addition, the rigid structure of government budget in the form of high percentages of wages and salaries, interest payments and subsidies makes it difficult to reduce spending. Moreover, the large budget deficit and the financing requirements, inefficient public expenditure management and revenue administration, flexible exchange rate, the large informal economy and the crowding-out effect of private sector.

Actually, Egypt has undertaken serious adjustment steps in the fiscal policy in cooperation with the IMF since 2016. So far, it has accomplished several subsidy reforms, debt servicing costs reduction, newly introduced value-added tax system and improved tax collection mechanism. Further progression has to be carried out in public procurement reform, tax base widening, budget deficit reduction and public sector role elimination in favor of the private sector. 


\section{References}

Abou Elseoud, M. (2018). “Keynesian Multiplier: Does it Matter to Egyptian Economy”, Journal of Islamic Financial Studies, No. 1.

- $\quad$ Alesina, A. \& Tabellini, G. (2005). Why is Fiscal Policy Often Procyclical?. National Bureau of Economic Research (NBER) Working Paper No. 11600.

- $\quad$ Alnashar, S. (2017). Egypt's Government Spending Multiplier: Its Size and Determinants. Economic Research Forum (ERF) Working Paper Series, No. 1165.

- $\quad$ Amisano, G. \& Giannini, C. (1997). Topics in Structural VAR Econometrics. $2^{\text {nd }}$ ed.. Springer-Verlag.

- Auerbach, A. \& Gorodnichenko, Y. (2012). "Measuring the Output Responses to Fiscal Policy", American Economic Journal: Economic Policy, 4, pp. 1-27.

- $\quad$ Batini, N.; Callegari, G. \& Melina, G. (2012). Successful Austerity in the United States, Europe and Japan. IMF Working Paper 12/190.

- $\quad$ Batini, N.; Eyraud, L. \& Weber, A. (2014a). A Simple Method to Compute Fiscal Multipliers. IMF Working Paper No. 93.

- $\quad$ Batini, N.; Eyraud, L.; Forni, L. \& Weber, A. (2014b). Fiscal Multipliers: Size, Determinants and Use in Macroeconomic Projections. IMF Technical Notes and Manuals.

- Ben Slimane, S. \& Ben Tahar, M. (2012). “Is Discretionary Fiscal Policy Effective? Evidences from Tunisia and Egypt", Review of Economics and Finance, Article ID: 1923-7529-2013-02-81-16.

- $\quad$ Blanchard, O. \& Perotti, R. (2002). “An Empirical Characterization of the Dynamic Effects of Changes in Government Spending and Taxes on Output", The Quarterly Journal of Economics, 117 (4), pp. 1329-1368.

- $\quad$ Boiciuc, I. (2015). "The Effects of Fiscal Policy Shocks in Romania: A SVAR Approach", Procedia Economics and Finance, 32, pp. 1131-1139.

- Çebi, C. (2015). Government Spending Multiplier in Turkey. Central Bank of the Republic of Turkey, Working paper No. 15/15.

- $\quad$ Cerisola, M.; Abdallah, C.; Davies, V. \& Fischer, M. (2015). Assessing the Impact of Fiscal Shocks on Output in MENAP Countries. IMF Technical Notes and Manual 15/01.

Christiano, L.; Eichenbaum, M. \& Rebelo, S. (2011). "When is the Government Spending Multiplier Large?", Journal of Political Economy, 119, pp. 78-121.

- Denis, X. \& Quinet, A. (2002). “The Comparative Effects of Fiscal Policy in Small and Large European Countries, Bank of Italy", The $4^{\text {th }}$ Workshop on Public Finance titled: The Impact of Fiscal Policy. Retrieved from: http://www.bancaditalia.it/studiricerche/convegni/atti/fisc_policy/i/1.5_ denis_and_quinet.pdf

- Deskar-Škrbić, M. \& Šimović, H. (2015). The size and Determinants of Fiscal Multipliers in Western Balkans: Comparing Croatia, Slovenia and Serbia, EFZG Working Paper Series No. 15-10.

- Economic Governance Support Unit of the European Parliament Note. (2013). The Fiscal Multipliers in Forecast Models: A Short Summary of the Recent Debate. Retrieved from: http://www. europarl.europa.eu/document/activities/cont/201301/20130130ATT60071/20130130ATT60071EN.pdf

- $\quad$ Efron, B. \& Tibshirani, R. J. (1993). An Introduction to the Bootstrap. Chapman \& Hall, New York.

- $\quad$ Fitch Solutions Macro Research Group, U.K. (2020). Egypt Country Risk Report: Includes 10 Year Forecast to 2028, Q1.

- $\quad$ Enders, W. (2010). Applied Econometric Time Series. John Wiley \& Sons, The United States of America. Eyraud, L. \& Weber, A. (2013). The Challenge of Debt Reduction During Fiscal Consolidation. IMF Working Paper 13/67. 
Fatas, A. \& Mihov, I. (2001). “Government size and Automatic Stabilizers: International Evidence", Journal of International Economics, 55(1), pp. 3-28.

- $\quad$ Ginannini, C. (1992). Topics in Structural VAR Econometrics. Springer-Verlag, Berlin, Heidelberg, Germany. Hassan, M. (2007). Procyclicality, Fiscal Dominance and the Effectiveness of Fiscal Policy in Egypt. Available at Social Science Research Network (SSRN). retrieved from: http://ssrn.com/abstract $=2004268$

- Hamr-Adams, A. \& Wong, M. (2018). Quantifying Fiscal Multipliers in New Zealand: the Evidence from SVAR Models. Reserve Bank of New Zealand Analytical Note Series, AN2018/5.

- Hemming, R.; Kell, M. \& Mahfouz, S. (2002). The Effectiveness of Fiscal Policy in Stimulating Economic Activity: A Review of the Literature. International Monetary Fund (IMF) Working Paper No. WP/02/208.

- Ilzetzki, E.; Mendoza, E. \& Vègh, C. (2011). How Big (Small?) are Fiscal Multipliers?. IMF Working Paper No. 52.

- Jooste, C.; Liu, G. \& Naraidoo, R. (2013). "Analysing the Effects of Fiscal Policy Shocks in the South African Economy", Economic Modelling, 32, pp. 215-224.

- Keynes, M. (1936). The General Theory of Employment, Interest and Money. Amherst, NY: Prometheus Books.

- Mançellari, A. (2011). Macroeconomic Effects of Fiscal Policy in Albania: A SVAR Approach. Bank of Albania Working paper No. 05(28).

- McCoy, D. (1997). How Useful is Structural VAR Analysis for Irish economics?. Central Bank of Ireland, Economic Analysis, Research and Publications Department, 2/RT/97.

- Mountford, A. \& Uhlig, H. (2002). What are the Effects of Fiscal Policy Shocks? Center for Economic Policy Research (CEPR), Discussion Paper No. 3338.

Mustea, L. (2015). "How Large are Fiscal Multipliers in the US?", Procedia Economics and Finance, El-Sevier, 20, pp. 423 - 427.

Nafie, Y. \& Atlam, B. (2019). "Fiscal Multiplier in Egypt: A SVAR Approach", The Social Sciences Medwell Journals,14 (6), pp. 255-265.

- Nicoletti, G. (1988). Private Consumption, Inflation and the 'Debt Neutrality Hypothesis': The Case of Eight OECD Countries. OECD Working Paper No. 50, Paris, Department of Economics and Statistics, OECD. Retrieved from: http://www.oecdilibrary.org/docserver/download/

- Perotti, R. (2004). Estimating the Effects of Fiscal policy in OECD Countries. Innocenzo Gaspara ini Institute for Economic Research (IGIER), Università Commerciale Luigi Bocconi. Retrieved from: http://www.igier.uni-bocconi.it/

- Ramey, V. \& Shapiro, M. (1998). "Costly Capital Reallocation and the Effects of Government Spending", Carnegie Rochester Conference on Public Policy, 48(1), pp. 145-194.

- Selwaness, I. \& Zaki, C. (2015). On the Interaction between Trade Reforms and Labor Market Regulation: Evidence from the MENA Countries' Labor Markets. Economic Research Forum (ERF) working paper No. 970.

- Sims, C. (1980). "Macroeconomics and Reality", Econometrica, 48, pp. 1-48. Retrieved from: http://www.jstor.org

- $\quad$ Surjaningsih, N.; Utari, G. \& Trisnanto, B. (2012). "The Impact of Fiscal Policy on the Output and Inflation", Bulletin of Monetary Economics and Banking, April, pp. 367-396.

- Van Aarle, B.; Garretsen, H. \& Gobbin, N. (2003). "Monetary and Fiscal Policy Transmission in the Euro-area: Evidence from a Structural VAR Analysis", Journal of Economics and Business, 55, pp. 609-638.

Whalen, C. \& Reichling, F. (2015). "The Fiscal Multiplier and Economic Policy Analysis in the United States", Contemporary Economic Policy, 33 (4), pp. 735-746. 